\title{
IMPACT OF DIGITIZATION AND MOBILE BANKING ON THE BANKING SECTOR STRUCTURE IN POLAND
}

\author{
WPŁYW CYFRYZACJI I BANKOWOŚCI MOBILNEJ \\ NA STRUKTURĘ SEKTORA BANKOWEGO W POLSCE
}

https://doi.org/10.34739/zn.2020.54.01

\author{
Sylwester Kozak ${ }^{1}$, Bartosz Golnik ${ }^{2}$ \\ ${ }^{1}$ Poland, Warsaw University of Life Sciences - SGGW, Institute of Economics and Finance \\ sylwester_kozak@sggw.edu.pl, ORCID: 0000-0001-9485-6704 \\ 2 Poland, Warsaw University of Life Sciences - SGGW, Institute of Economics and Finance \\ bartosz_golnik@sggw.edu.pl, ORCID: 0000-0003-0220-3955
}

\begin{abstract}
The article presents the results of examining the changes that have occurred in connection with the digitization of banking in Poland and its impact on this segment. The data is taken from the National Bank of Poland, the Polish Financial Supervision Authority, and the Prnews.pl website. A descriptive, statistical and Pearson correlation method were used. The results indicate an increasing share of customers using banking products in a digital way. The number of both website and mobile applications customers is growing. Despite the general increase in the number of people using banks, the number of bank branches as well as the employees working them has decreased. Mobile applications may soon become the main sales and service channel for banking products, the number of customers of banks using them regularly increases. In fact, the rise in digitization for banking and the decrease in the number of branches and employees are strongly correlated. The increasing usage of online and mobile banking is influenced by convenience, availability, and a reduction in the time customers spend on purchasing and servicing their products. Banks are interested in developing these types of services in order to both meet the changing needs of customers and to save on operating costs.
\end{abstract}

Keywords: Poland, banking sector, digitization, mobile banking

\begin{abstract}
Abstrakt: Artykuł prezentuje wyniki badania zmian, jakie nastąpiły w związku z cyfryzacją bankowości w Polsce i jej wpływem na kształtowanie się tego segmentu. Dane pochodzą z Narodowego Banku Polskiego, Komisji Nadzoru Finansowego, serwisu Prnews.pl. Zastosowano metodę opisową, statystyczną, korelacji Pearsona. Wyniki wskazują na zwiększający się udział klientów korzystających z produktów bankowych w sposób cyfrowy. Rośnie liczba zarówno klientów serwisów www, jak i aplikacji mobilnych. Przy ogólnym wzroście liczby osób ubankowionych, maleje liczba oddziałów banków, a także pracowników w nich zatrudnionych. Głównym kanałem sprzedaży i obsługi produktów bankowych mogą wkrótce zostać aplikacje mobilne, liczba klientów banków z nich korzystających regularnie wzrasta. Zjawisko coraz powszechniejszego ucyfrowienia bankowości i spadku liczby oddziałów oraz pracowników są ze sobą silnie skorelowane. Na coraz powszechniejsze wykorzystanie bankowości internetowej i mobilnej wpływ mają wygoda, dostępność, a także redukcja czasu poświęcanego przez klientów na zakup i obsługę posiadanych produktów. Banki są zainteresowane rozwojem tego typu usług zarówno celem zaspokojenia zmieniających się potrzeb klientów, jak i oszczędności kosztów operacyjnych.
\end{abstract}

Słowa kluczowe: Polska, sektor bankowy, cyfryzacja, bankowość mobilna

\section{Introduction}

Digitization has been a phenomenon commonly known in many segments of the national economy in recent years. Its idea is to provide customers with products and services in digital form, using devices with Internet access, via computers and mobile phones (Savic, 2019). These processes are also intensively developing in the banking sector. The development and spread of digitization has brought many benefits to the potential customers of banking services, thanks in particular to the shortening of the time of banking operations and the increase in their availability. Digitization contributes to simplifying the processes of obtaining information about the banking offer, products and subsequent after-sales service. Its growing importance is connected with the growing social tendency to carry out as many activities as possible, quickly, conveniently and in a simple way. In addition to the customers of financial services and products, the benefits of digitization 
are also used by suppliers of a wide range of services and products. This process has contributed to a reduction of the operating costs and increasing the potential for acquiring new customers (Parviainen and others, 2017). The beneficiaries of the development of sales in digital form are therefore all the participants of a given market who want to adjust the way they operate to the growing technological level of the economy. Entities that have been building their position through an extensive network of stationary branches are reluctant to accept this process. Indeed, they usually treat digital sales as a minority distribution channel for their products.

Providing remote sales processes and customer service has become particularly important thanks to smartphones. Their role in the distribution of products and services has become important for most sectors of the economy, including banking. Currently, cell phones are used not only to make calls and send messages, but also to make purchases, investments, payments, manage time, watch video content or listen to music (Sarwar, Soomro, 2013). Institutions, including banks, quickly observed the potential to increase their sales through digital channels. In formulating their strategy, they take into account the fact that consumer interest shifts from shopping in stationary stores to online shopping using computers and mobile phones (Bodla, Saini, 2017). Due to the significant increase in the number of processes and services available to customers from a mobile phone, banks are trying to further encourage customers to this way of using financial services. In order to achieve this goal, they conduct educational activities in order to improve the skills of customers in terms of remote shopping and customer friendly applications. The significance of these processes in banking activity means that currently no bank can afford to neglect the development of mobile banking applications.

\section{The aim, materials and research methods}

The problem of shifting banking operations from stationary to electronic banking, including mobile banking, is not a frequent subject of research. This paper expands current knowledge about the transformation in the banking service of individual customers. The purpose of the article is to describe and evaluate the digitization process, mainly related to mobile banking, taking place in the Polish banking sector, as well as to present the changes it has brought about in terms of the structure of this sector.

The article has the following structure. The next section presents a review of the literature on the use of internet and mobile communications in retail banking, later the sources of data and the research method used are described. The final part presents the results of research and their discussion. The whole paper is summarized in the conclusions.

\section{The use of electronic channels in banking - literature review}

The digital transformation of banking activities is a commonly perceived topic both inside the banking world and in its external environment. Druszcz (2017) notes that the evolution of society, which was caused by the use of the Internet in almost all spheres of human life, forced banks to automate and digitize all processes and products offered. In order to meet the requirements of a modern customer, banks change their strategies targeting his needs as the top priority. Digitization is therefore necessary in the context of 'customer-' and socio-centric marketing orientation. The natural process of pursuing customers of financial institutions is to ensure their own convenience and ease of access. Therefore, activities aimed at maintaining branch sales are becoming inefficient and non-marketable. Charkha and Lanjekar (2018) conclude that the development of online banking has become an essential tool for banks in the fight for market survival (Charkha, Lanjekar, 2018).

An important advantage of digitization is the fact that broad access to mobile banking can help equalize opportunities when it comes to accessing financial services in rural and less urbanized areas. Malaquias and Silva (2020), on the basis of surveys conducted among farmers from 20 regions of Brazil, found that the scale of using mobile banking by farmers is positively influenced by its usefulness and sense of security during the processing of banking transactions. The developpment of banking digitization motivates the management boards of banks to properly consider the role that customers attach to the issue of trust in financial institutions. Before the development of digital services, the sale of banking products had specific features, including significant formalization of the bank-customer relationship, formalized provisions and contracts. Digitalization has systematically blurred these differences, and banking products are purchased using mobile devices in a similar way as any other product, including food or clothing.

However, trust and a sense of security remain an important feature of the bank-customer relationship. Alkhowaiter (2020) examining the financial system in the countries of the Gulf region notes that the global reach and widespread use of the Internet and mobile devices have contributed to the development of digital payments. In his research, he notes that factors increasing the use 
of the digital payment system are trust in payment institutions, security and usability of digital payment services. Clients are aware that financial institutions often manage their life savings and expect exceptional professionalism from them. Similar conclusions come Rao and others (2013). Based on a survey of the banking sector in India, Rao noted that by developing mobile banking, banks are taking steps to increase customers' sense of security and privacy.

The development of mobile banking is changing the organization and structure of the banking sector. Jolly (2016), researching the banking sector in Asian countries, notes that digitization has reduced operating costs at banks, and commensurately the bank charges incurred by their customers. Customers gain access to a wider range of banking products while maintaining their current or lower costs. At the same time, these products are available every day of the week. Such features are conducive to an increase in demand for electronic banking services in the examined banks. On the other hand, for banks, transferring a significant part of transactions to the online world allows for a massive reduction in operating costs and the limitation of branches.

Digitization has also brought about changes in the employment structure of banks. Reczulski (2019) states that providing customers with a growing number of products and services in a digital way reduces the number of jobs at banks in Poland. However, this process brings both benefits and threats, including pay cuts or layoffs at banks. De, Pandey and Pal (2020) emphasize the important role that the COVID-19 epidemic has played in the course of digitization. The need to use remote banking services sales channels has accelerated the increase in the number of people buying banking products this way. They predict that sales and service of bank customers at bank branches may not return to levels achieved in the past.

Shankar, Jebarajakirthy and Ashaduzzaman (2020) emphasize the importance of mobile banking in the recommendation process of a given bank's services. So far, customers have recommended specific products and services mainly in the real world. With the development of digital services, this activity has gradually been transferred to the Internet, making it the main source of consumer opinion. This has forced banks to devote more attention to maintaining customer satisfaction in order to obtain recommendations for their services.

\section{The usage of mobile telephony in banking}

One of the first entities that decided to monetize the potential generated by the development of the Internet was Amazon (Sadq, Sabir, \& Saeed,
2018). In 1995, Amazon launched a digital book distribution system. Other sales-related activities that were transferred to the digital channel were, among others, publishing offers for more customers and promotion of the brand. This brought companies a significant reduction in operating costs. Digital expansion became fully justified because it started to provide real value to customers. It provided greater availability, time savings and enabled obtaining information on the availability of a specific product in real time. The introduction of remote sales did not negatively affect other customers who have not yet decided to use it. This principle has been maintained in the banking sector, where most services are still available in stationary branches. It should also be expected that despite the extensive digitization of banking activities, banks will not stop selling their products in branches, particularly given that this form of service is preferred by a large group of customers.

It is worth noting, however, that the appearance of the COVID-19 pandemic has accelerated the process of transferring banking operations to mobile channels. Banks, like other commercial institutions, are taking advantage of the increasing availability of smartphones. In addition to providing another tool for existing customers, this action also looks to meet the expectations of a new group of consumers of financial services, the so-called mobile first and mobile only (Sridhar, 2014; Correa, Pavez, \& Contreras, 2018). These are groups who prefer shopping and sales and after-sales service using a mobile phone. While for mobile first customers, in the case of an absence of the availability of the offer on smartphones, there are alternative preferences for purchasing products on the website or in a branch, the mobile only group has very clearly defined shopping preferences. The failure of banks to provide products through mobile applications will result in reduced sales and difficulties in maintaining existing customers, especially those who prefer mobile communication with the bank. For this reason, banks are closely observing the progressive dynamics of financial activation of mobile applications, the number of logins to banking services and mobile payments for purchases. A well designed, convenient to use application can be a significant competitive advantage for the bank and help attract customers.

In Poland, mobile banking is developed mostly in the group of the largest banks and the number of customers regularly using it is systematically increasing (Table 1 ). In the years 2016-2019, in each bank belonging to this group, the number of mobile banking users increased annually by 350,000 , c. a. by $27 \%$. The highest 
increases in absolute terms were recorded by PKO $\mathrm{BP}$, around 590 thousand per year. The largest annual growth dynamics in the number of mobile banking users was achieved by two banks, Bank Pekao (35.7\%) and Bank Millennium (33.8\%). However, there is a strong diversity in the market for these services between the group of the largest and smallest banks, and the market for these services is highly concentrated. The five largest banks operate around $82 \%$ of all mobile banking accounts (Table 1). The level of concentration of this market segment is therefore higher than the level of concentration of assets of the banking sector, which at the end of 2019 , measured by the CR5 ratio for assets, was $50.1 \%$ (KNF data Information on the banking sector in Poland in 2019.

Table 1. Number of mobile banking users in the six largest banks in Poland in 2016-2019

\begin{tabular}{lrrrrrr}
\hline \multicolumn{1}{c}{ Bank } & \multirow{2}{*}{$\mathbf{2 0 1 6}$} & \multirow{2}{*}{$\mathbf{2 0 1 7}$} & \multirow{2}{*}{$\mathbf{2 0 1 8}$} & \multirow{2}{*}{$\mathbf{2 0 1 9}$} & \multicolumn{2}{c}{ Average annual growth } \\
\cline { 6 - 8 } & & & & & Number & Dynamics \\
\hline PKO BP & 1652460 & 2258095 & 2785645 & 3421767 & 589769 & $27.62 \%$ \\
mBank & 1327555 & 1607904 & 1919907 & 2258230 & 310225 & $19.38 \%$ \\
ING Bank Śląski & 1048486 & 1461624 & 1754068 & 2082000 & 344505 & $26.04 \%$ \\
Bank Pekao & 672000 & 938000 & 1262983 & 1678597 & 335532 & $35.71 \%$ \\
Santander BP & 974336 & 1193282 & 1457530 & 1659597 & 228420 & $19.49 \%$ \\
Bank Millennium & 595756 & 711000 & 963000 & 1410855 & 271700 & $33.76 \%$ \\
Banking sector & 6834767 & 8944401 & 11303853 & 13891784 & 2352339 & $26.71 \%$ \\
\hline
\end{tabular}

Source: own elaboration based on https://prnews.pl/ (access: 30.06.2020).

In Poland it is possible to observe customer preference for frequent use of remote channels. Customers do not use the convenience of an extensive network of stationary branches, while the advantage of the bank's offer is a greater number of mobile banking products available. In three years, the number of mobile banking clients in Poland has almost doubled, reaching nearly 14 million people at the end of 2019. This means that currently a significant part of Polish society uses this channel of communication with the bank. This number tends to increase due to the widespread information on the possibilities offered by mobile banking applications, as well as due to the time savings and visits to bank branches associated with their use, which is of particular importance in connection with the prevailing COVID-19 pandemic.

Banks recognize the possibilities of sales development via mobile channels and treat it as a tool to improve their cost effectiveness. Although initially mobile applications were less numerous compared to classical website banking, due to the strong dynamics of growth, the number of mobile banking customers is already much similar to the website one. Customers' preferences are increasingly shifting towards convenient and regularly extended services available from the phone. This is also due to the fact that mobile phones are treated not only as a communication tool, but also as a means of identification before public administration representatives. They have also become an inseparable part of everyday life; and give the opportunity to check the status of a bank account, make a transfer or withdraw cash at an ATM at any time.

Such usefulness of mobile banking means that at the end of 2019 , about $39 \%$ of customers who have an agreement with the bank signed to use online banking also use mobile applications (Fig. 1). It should be expected that in the coming years the growth of users of mobile applications will continue to rise, but with a much slower pace. This is due to the fact that many bank customers have already adopted mobile banking services. On the other hand, the number and amount of operations carried out can be expected to increase.

The higher dynamics of the increase in the number of customers using mobile than online websites indicates a changing consumer preference towards this particular service channel. Mobile applications offer an increasing number of possibilities and therefore financial institutions treat their development as a priority, implementing new functions and processes to this sales channel. 


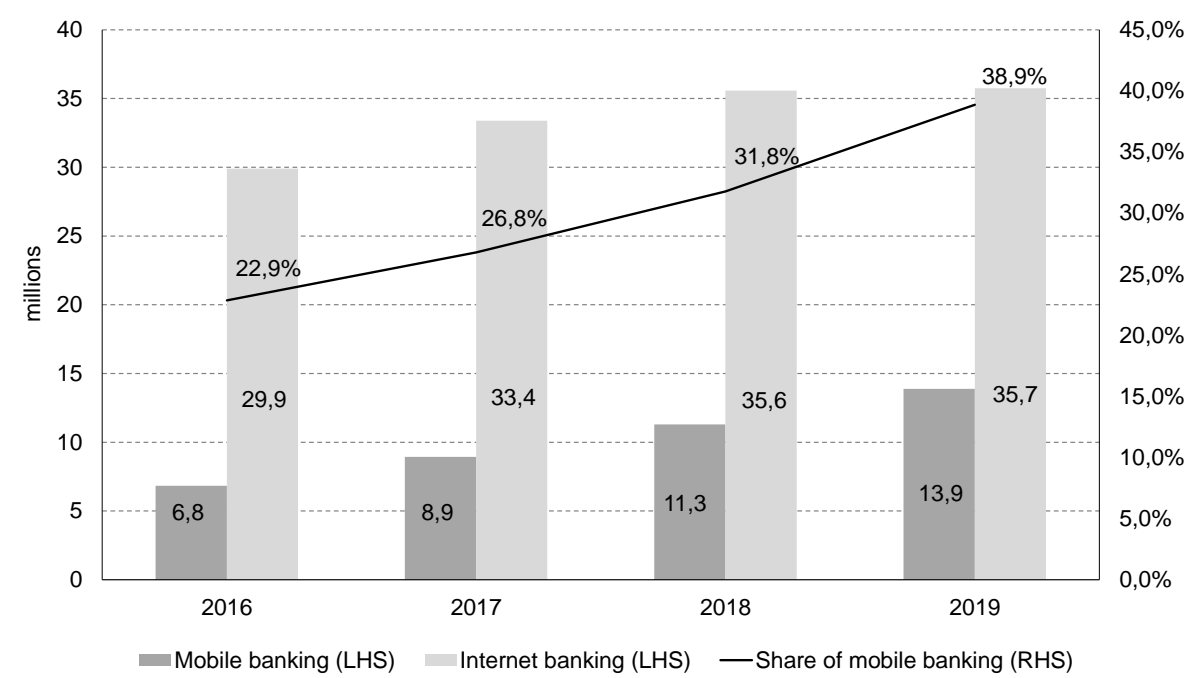

Figure 1. Number of users of online and mobile banking in Poland in 2016-2019

Note: user - a customer who has an agreement with the bank to access online or mobile banking.

Source: own elaboration based on https://prnews.pl/ (access: 30.06.2020).

\section{Mobile banking and changes in the structure of the banking sector}

The development of mobile banking and the increase in the number of bank accounts operated in this way is connected with the process of reducing the network of stationary branches and the number of employees working in them. In the years 2016-2019, the number of bank branches systematically decreased on average 230 per year. The largest decrease (by 407 branches) was recorded in 2017 (Fig. 2). The number of bank employees had a similar trend. On average, the number of employees decreased by around 3.5 thousand per year. It is characteristic that in 2019, despite the increase in the number of bank branches, the number of reduced jobs in the banking sector was the largest in the analyzed period, i.e. 5.7 thousand. This means that the number of employees servicing customers in the branches decreased, but also that customers needed a much reduced number of banking services to be provided. Some of the banking activities have already been carried out by customers using online and mobile banking.

The change in the banking sector customer service system and the transfer of the implementation of a significant part of banking operations to the digital channel, including the mobile one, is influencing the decrease of share of branch employees in the total number of bank employees (Fig. 3).

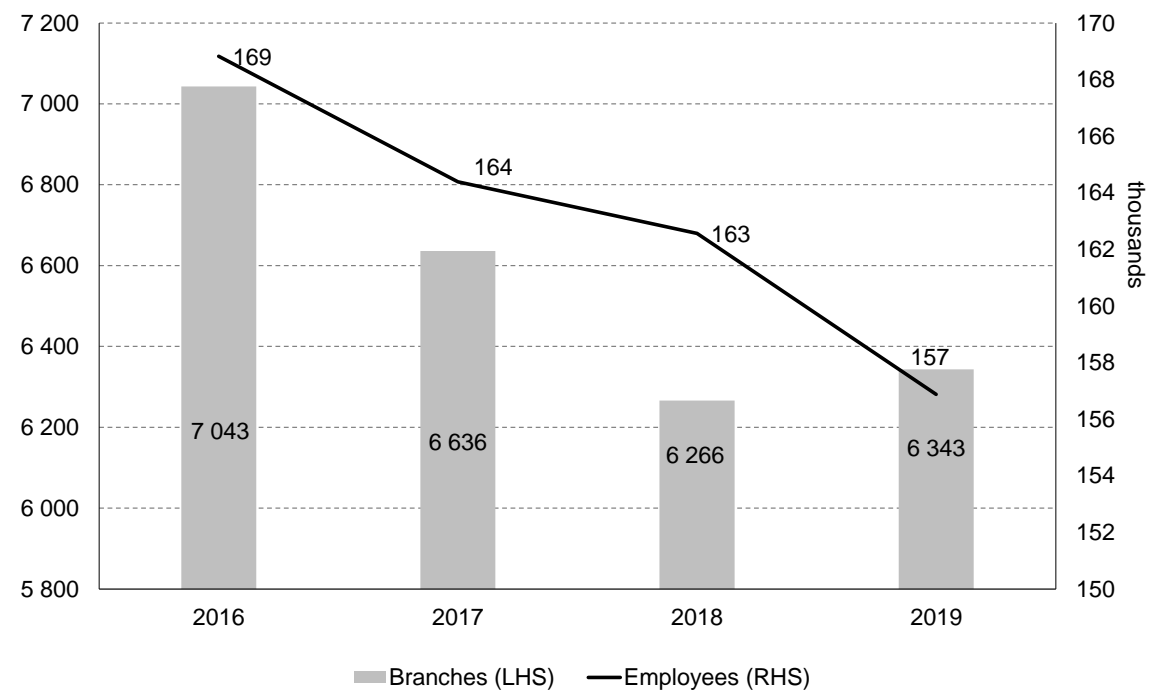

Figure 2. Number of branches and bank employees in Poland in 2016-2019 Source: own elaboration based on KNF data. 


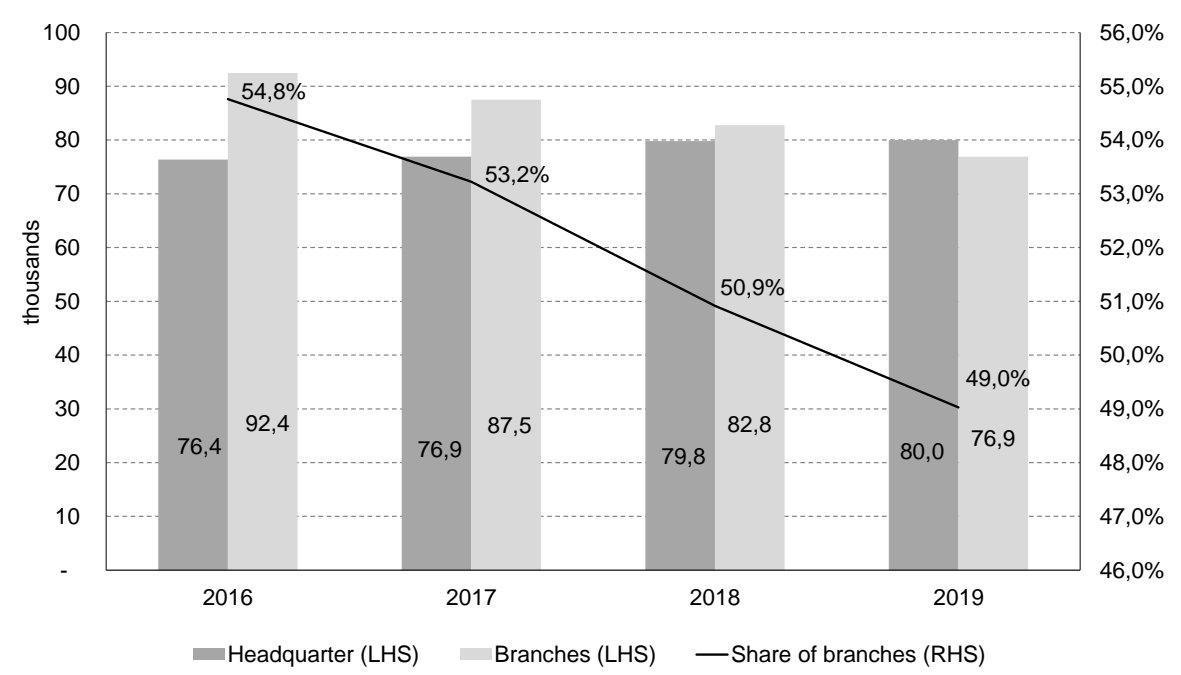

Figure 3. Number of employees of headquarters and branches in the banking sector in Poland in 2016-2019 Source: own elaboration based on KNF data.

The processes of developing mobile banking and changes in the number of branches of banks are negatively correlated. Correlation rates between the number of mobile banking accounts and the number of branches estimates as $-89 \%$, while between the number of branch employees $98 \%$ (Table 2). The number of mobile banking users and the share of branch employees in the total number of banking employees are correlated to a similarly negative degree. These relationships indicate that the development of mobile banking is one of the reasons for limiting the number of bank branches and the banking activities carried out in them that require the service of a bank employee. Bank branches are becoming a place of financial advice, including advice connected with investing customer savings.

Table 2. Mobile banking and the number of bank branches and their employees in Poland in 2016-2019

\begin{tabular}{lrrr} 
& $\begin{array}{r}\text { The number of mobile } \\
\text { banking users and } \\
\text { the number of bank } \\
\text { branches }\end{array}$ & $\begin{array}{r}\text { The number of users } \\
\text { of mobile banking } \\
\text { and the number of } \\
\text { employees of branches }\end{array}$ & $\begin{array}{r}\text { The number of users } \\
\text { of mobile banking } \\
\text { and the share of }\end{array}$ \\
\hline Pearson correlation index & $-89 \%$ & $-98 \%$ & $-98 \%$ \\
\hline
\end{tabular}

Source: own elaboration based on KNF and https://prnews.pl/ (access: 30.06.2020).

\section{Conclusions}

In recent years, digitization has been a phenomenon commonly found in many segments of the national economy, including in the banking sector. It simplifies the implementation of information acquisition and processing and contributes to shortening the time of banking operations and increasing their availability to customers.

In Poland, in 2016-2019 mobile banking developed mainly in the group of the largest banks, leading to a strong concentration of this segment of the banking market. At the end of 2019, the concentration of mobile banking, measured by the CR5 indicator, amounted to $82 \%$ and was significantly higher than the concentration level of banking sector assets of $51 \%$.
The number of customers of mobile banking in the group of the largest banks increased by an average of 350,000 in one year, i.e. around $27 \%$. Although initially internet banking was much more common, due to the strong dynamics of growth, the number of mobile banking customers has significantly approached the number of online banking customers. Availability, simplicity and security of service led to the fact that at the end of 2019 , approximately $39 \%$ of online banking customers also used mobile banking.

The progress in the digitization of banking operations and the development of mobile banking have contributed to reducing the network of bank branches and the number of employees of banks as well as reducing the share of employees of bank branches in the total number of employees. 
Correlation rates between the change in the number of mobile banking clients and changes in the number of branches and employed bank employees were negative and amounted to $89 \%$ and $98 \%$.

\section{References}

Alkhowaiter, W.A. (2020). Digital payment and banking adoption research in Gulf countries: A systematic literature review. International Journal of Information Management Volume (53), 1-17. https://doi.org/10.1016/j.jinfomgt. 2020.102102.

Bodla, B.S., Saini, P. (2017). Online shopping: A study of consumers' preference for various products and e-retailers. TSMEJM (7)2.

Charkha, S.L., Lanjekar, J.R. (2018). A Study Of Performance of Online Banking In Comparison with Traditional Banking and its Impact on Traditional Banking. Published in Research Gate.

Correa, T., Pavez I, Contreras J. (2018). Digital inclusion through mobile phones: a comparison between mobile-only and computer users in internet access, skills and use. Information Communication and Society.

De, R., Pandey, N., Pal, A., (2020). Impact of digital surge during Covid-19 pandemic: A viewpoint on research and practice. International Journal of Information Management, DOI: 10.1016/ j.ijinfomgt.2020. 102171.

Druszcz, P. (2017). Digitalizacja produktów bankowych jako cel strategiczny uczestników polskiego sektora bankowego [The digitization of banking products as a strategic aim on the Polish banking sector]. Ruch prawny, ekonomiczny i socjologiczny, 79(1), 237-250.

Jolly, V., (2016). The influence of Internet banking on the efficiency and cost savings for banks customers. International Social Sciences Management, 3 (3), 163-170, DOI: 10.3126/ ijssm.v3i3.15257.

Malaquias, R.F, Silva, A.F. (2020). Understanding the use of mobile banking in rural areas of Brazil. Technology in Society, 62, https://doi.org/10.1016/j.techsoc.2020.101260.

Parviainen, P., Kääriäinen, J., Tihinen, M., Teppola, S. (2017). Tackling the digitalization challenge: how to benefit from digitalization in practice. International Journal of Information Systems and Project Management, 5 (1).

Rao, A., Singh, S.D., Vara, S., Reddy, P. (2013). Online banking: An introspection, Conference: International Management Convention, At Bhubaneshwar.
Reczulski, P. (2019). Wpływ digitalizacji sektora bankowego w Polsce na strukturę zatrudnienia $\mathrm{w}$ bankowości [The impact of digitisation on recruitment in the banking sector]. Zeszyty Naukowe ZPSB Firma i Rynek, 1(55), 163-171.

Sadq, Z.M., Sabir, H.N., Hama Saeed, V.S. (2018). Analyzing the Amazon success strategies. Journal of Process Management - New Technologies, 6.

Sarwar, M., Soomro T.R. (2013). Impact of Smartphone's on Society. European Journal of Scientific Research, 98 (2).

Shankar, A., Jebarajakirthy, C., Ashaduzzaman, Md. (2020). How do electronic word of mouth practices contribute to mobile banking adoption? Journal of Retailing and Consumer Services, (52), https://doi.org/10.1016/j. jretconser.2019.101920.

Sridhar, V. (2014). Analysis of Factors Influencing Mobile First Strategy in India. Review of Market Integration 6(1). 